漬消毒の検討は, $0.2 \mu$ Nuclepore Membrane Filter 法で培養は Brain Heart Infusion 寒天 培地を用飞 $32^{\circ} \mathrm{C}, 48$ 洔間培養した。

2. 実験成績: $2 \%$ CIDEX水溶液の MIC は菌 量 $10^{7}$ で 10,000 である.これは BHI 培地成 分により不活化されたためである.なぜなら生 食水の菌浮遊液では $2500 \mathrm{r} / \mathrm{cc}$ まで殺菌作用力 を認めている。また, CIDEX 1：BHI. Broth 1.25, 同比 $1: 37,1: 5$ の容量比で 6 種の細菌 $10^{6}$ に対与る抗菌作用力は $5 \%$ 割りに BHI. Broth 添加群はすべてが殺菌された. 次に家東 血清を CIDEX 1：血清3.7の比で希釈し殺菌力
をみると $3333 \gamma / \mathrm{cc}$ まで菌量 $10^{\mathbf{6}}$ に対し殺菌した. 一方, 枯草菌芽胞に対しては, 菌量 $10^{8} / \mathrm{cc}$ に対 L $2 \% \mathrm{G}$.A. 水溶液は $\mathrm{pH} 8,7$ は $\mathrm{pH} 6$ より も殺菌速度が早い. 同 G.A. 液に $5 \%, 10 \%$ の 割りに家鬼血清を加えた場合も同様の殺菌速度 を示した。

麻酔器具 (チューブ, エアウェイ等) 使用直 後の污染菌数は520万〜 7300万であるが，2\%活 性化 CIDEX 水溶液に30分浸液消毒法によって 十分に消毒される. 浸漬後は一定容器内の水で 1 回ゆすぐと $90 \%$ 以上の G.A.は除去でき 4 度 これを繰返すと G.A.は検出されなくなる.

\title{
7 手術前手洗い水の細菌污染とその対策
}

当手術部の術前手洗い水を対象に手洗い水の 細菌污染状態を調べた。

菌数は蛇口採水で $10 \sim 20 / \mathrm{ml}$ で, 菌種は鞭毛 をもつグラム陽性桿菌と2 種類のグラム陰性楿 菌が検出された。 これらの菌はいずれも加熱後 の水道水中で増殖可能で, 手洗い水製造装置の 加熱後の貯水槽の一部之蛇口までの配管中が増 殖個所であった。

污染経路として原水（水道水）の細菌污染と 空中細菌による水の污染を検討したが，常用さ れている蛇口から採水した水道水の菌数は 6 〜 $57 / l$ で少なく，菌種も1種類であった. いっぽ う空中細菌の中には水中で増殖可能な菌が実験 的にとらえただけでも10種類以上あり，污染源 となる可能性が強い．

これら水中で増殖可能な菌のなかの一部の菌 は低濃度の活性塩素, ヒビテンなどに抵抗性を 示したが，熱には比較的弱く, $100^{\circ} \mathrm{C} 15$ 分以上 の熱に耐える菌はみられなかった。

対策として次の 5 つの方法を個々に検討した。

\section{東医歯大 手術部 \\ 宮前卓之古橋正吉}

加熱殺菌法, 薬物殺菌法 (主に活性塩素) は 有効な方法である.しかし, 加熱殺菌法の場合 は活性塩素が失なわれるため冷却後細菌の増殖 がおこりやすくなるので回路を閉鎖型として, 空中細菌の污染も受けないように寸る必要があ る.

沁過法としてニュークリポア メンブランフ イルタを検討したが除菌が不完全であった。フ ィルタ表裏两面の走査型電顕写真で孔径が不均 一であることがみとめられ, 菌の透過が推測さ 扎る

紫外線殺菌法も短期間使用で 95 (7.3l/分) 99\% (4l/分) の減菌効果があったが，長期連用 する場合には蛇口附近での再污染が䀣念される.

手洗い水の細菌污染で問題となるのは, 低栄 養要求性菌でるるが蒸留水 (蒸留法) 中では高 栄養要求性菌はもち万几低栄養要求性菌もほと んど増殖しない。

この点で, 手洗い水は蒸留水とするのが現状 では最もよいと考える。 